\title{
HIGHLIGHT
}

\section{Extended pluripotent stem cells facilitate mouse model generation}

\author{
Guanghai Xiang ${ }^{1,2}$, Haoyi Wang ${ }^{1,2 \bowtie}$ \\ ${ }^{1}$ State Key Laboratory of Stem Cell and Reproductive Biology, Institute of Zoology, Chinese Academy of Sciences, Beijing \\ 100101, China \\ 2 University of Chinese Academy of Sciences, Beijing 100049, China \\ $\triangle$ Correspondence: wanghaoyi@ioz.ac.cn (H. Wang)
}

Mouse embryonic stem (mES) cells, established in 1981 (Evans and Kaufman, 1981; Martin, 1981), were derived from the inner cell mass (ICM) of blastocysts and can be expanded in vitro for many passages, maintaining normal karyotype and differentiation potential. Upon introduction into blastocysts, mES cells can differentiate into all three germ layers, contributing to all the somatic lineages and germline. In 1998, James Thompson derived human embryonic stem (hES) cells from the ICM of human blastocysts (Thomson et al., 1998). Intriguingly, hES cells have many characteristics different from mES cells, including morphology and signaling pathway maintaining pluripotency (Burdon et al., 2002; Forsyth et al., 2002; James et al., 2005). In 2007, mouse epiblast stem cells (EpiSCs) were derived from the epiblast of post-implantation mouse embryo (Brons et al., 2007; Tesar et al., 2007). These mouse EpiSCs have distinct molecular and functional properties from mouse ES cells, while resemble human ES cells in many ways. Mouse ES cells and EpiSCs represent the in vitro counterpart of preimplantation and postimplantation epiblast, and these two phases were defined as naïve and primed pluripotency respectively (Nichols and Smith, 2009). The traditional human ES cells are similar to mouse EpiSCs as a primed pluripotent state. Recently, several groups described culture conditions to induce and maintain human ES cells at a naïve-like state (Chan et al., 2013; Duggal et al., 2015; Gafni et al., 2013; Takashima et al., 2014; Theunissen et al., 2014; Valamehr et al., 2014; Ware et al., 2014), suggesting that human pluripotent stem cells also have these two phases.

Although pluripotent stem cells can differentiate into all the cell types in an adult organism, neither naïve ES cells nor EpiSCs could contribute to extra-embryonic (ExEm) tissues, which mediate uterine implantation and subsequent maternal nutrition of the growing embryo and fetus (Beddington and Robertson, 1989). In 2017, two groups reported the derivation of extended (or expanded) pluripotent stem (EPS) cells, which could generate both embryonic and extra-embryonic lineages in vivo (Yang et al., 2017a, b). EPS cells could be efficiently derived from early embryos and through reprogramming, both in human and mouse. Remarkably, one single EPS cell injected into eight-cell embryo could contribute to both the embryo proper and the trophectoderm lineages. Single-cell transcriptome analysis revealed enrichment for blastomere-specific signature in EPS cells.

One of the most important applications of mES cells is to generate knockout mice. In this issue of Protein \& Cell, two papers from Deng lab (Du et al., 2018; Li et al., 2018) showed that, compared to mES cells, EPS cells have superior advantages in generating mouse models. $\mathrm{Li}$ et al. showed that EPS cells had genetic and epigenetic stability better than ES cells after long-term culturing. When single EPS or ES cell was injected into eight cell embryos, EPS cells showed much better chimeric contribution capability. They further knocked human IL 3 and IL6 genes into mouse endogenous loci using CRISPR-Cas9. After injecting these engineered EPS cells into tetraploid embryos, they were able to derive IL3 and IL6 knock-in mice directly with an efficiency of one mouse out of ten injected embryos, while injecting ES cells failed to obtain any live born. These results showed that gene targeting in mouse EPS cells combined with tetraploid complementation (Nagy et al., 1993) can efficiently produce mouse models in approximately 2-3 months.

Since only a few mouse strains are permissive for ES cells derivation, Du and colleagues attempted to derive EPS cells from non-permissive NOD-scid $1 / 2 \mathrm{rg}^{-1-}$ strain. They successfully established EPS cells from NOD-scid $112 \mathrm{rg}^{-/}$ stain via two methods: de novo derivation from blastocysts and chemical reprogramming from embryonic fibroblasts. In vitro long-term culture showed these EPS cells kept normal 
karyotypes, and contributed to both ICM and trophectoderm lineages when injected into embryos. They also showed that gene targeting worked efficiently in EPS cells derived from NOD-scid $1 / 2 \mathrm{rg}^{-1-}$ background.

Genetically modified mouse models are invaluable tools for biology and biomedical research. These two studies raised some exciting opportunities for improving mouse model generation. Although CRISPR-Cas9 based gene editing in zygote could generate knockout and knock-in mice efficiently (Wang et al., 2013; Yang et al., 2013), more sophisticated manipulation such as large transgene knock-in and conditional allele generation could still be easier using gene targeting in pluripotent stem cells. With superior genetic and epigenetic stability and efficient tetraploid complement capability, EPS cells could serve as a very useful system to generate genetically modified mouse models. With the help of CRISPR-Cas9, multiple sophisticated genetic modifications can be engineered in EPS cells and then mouse will be derived directly from these cells via tetraploid complementation.

Since NOD-scid $/ 12 \mathrm{rg}^{-1-}$ strain is highly immunodeficient, it is widely used for generating humanized mouse models, such as patient derived xenograft (PDX) model. It will be interesting to know whether the results of these two studies can be combined to generate human IL6 knock-in NOD-scid $1 / 2 \mathrm{rg}^{-1-}$ mouse through tetraploid complementation. If this is successful, it sure will facilitate the generation of more sophisticated models on this important strain background.

Although EPS cells have developmental potency to contribute to both embryonic and extra-embryonic lineages, they are still not bona fide totipotent (Jaenisch et al., 2018). As Li and colleagues showed, when one single EPS cell was injected into eight cell embryos, about $30 \%$ of the E10.5 embryos have more than $50 \%$ cells coming from this single injected EPS cell. This suggests that EPS cells have better development potential than natural blastomere! Upon further development of culture condition, whether EPS cells alone can contribute to the entire embryos is an extremely exciting question to ask.

So far EPS cells have only been derived from human and a few mouse strains, another very exciting future direction is to derive EPS cells from more species, especially in livestock animals that were non-permissive to pluripotent stem cell establishment. If successful, this will greatly improve the genetic modification and production of other species such as non-human primate and livestock.

\section{NOTES}

This work was supported by the National Natural Science Foundation of China (No. 31471215), the Strategic Priority Research Program of Chinese Academy of Sciences (No. XDA16010205), and the National Key Research and Development Program of China (No. 2016YFA0101402).

The authors declare that they have no conflict of interest.

\section{OPEN ACCESS}

This article is distributed under the terms of the Creative Commons Attribution 4.0 International License (http://creativecommons.org/ licenses/by/4.0/), which permits unrestricted use, distribution, and reproduction in any medium, provided you give appropriate credit to the original author(s) and the source, provide a link to the Creative Commons license, and indicate if changes were made.

\section{REFERENCES}

Beddington RS, Robertson EJ (1989) An assessment of the developmental potential of embryonic stem cells in the midgestation mouse embryo. Development 105:733-737

Brons IG, Smithers LE, Trotter MW, Rugg-Gunn P, Sun B, de Sousa Chuva, Lopes SM, Howlett SK, Clarkson A, Ahrlund-Richter L et al (2007) Derivation of pluripotent epiblast stem cells from mammalian embryos. Nature 448:191-195

Burdon T, Smith A, Savatier P (2002) Signalling, cell cycle and pluripotency in embryonic stem cells. Trends Cell Biol 12:432438

Chan YS, Goke J, Ng JH, Lu X, Gonzales KA, Tan CP, Tng WQ, Hong ZZ, Lim YS, Ng HH (2013) Induction of a human pluripotent state with distinct regulatory circuitry that resembles preimplantation epiblast. Cell Stem Cell 13:663-675

Du Y, Wang T, Xu J, Zhao C, Li H, Fu Y, Xu Y, Xie L, Zhao J, Yang W et al (2018) Efficient derivation of extended pluripotent stem cells from NOD-scid II2rg(-/-) mice. Protein Cell. https://doi.org/10. 1007/s13238-018-0558-Z

Duggal G, Warrier S, Ghimire S, Broekaert D, Van der Jeught M, Lierman S, Deroo T, Peelman L, Van Soom A, Cornelissen R et al (2015) Alternative routes to induce naive pluripotency in human embryonic stem cells. Stem Cells 33:2686-2698

Evans MJ, Kaufman MH (1981) Establishment in culture of pluripotential cells from mouse embryos. Nature 292:154-156

Forsyth NR, Wright WE, Shay JW (2002) Telomerase and differentiation in multicellular organisms: turn it off, turn it on, and turn it off again. Differentiation 69:188-197

Gafni O, Weinberger L, Mansour AA, Manor YS, Chomsky E, BenYosef D, Kalma Y, Viukov S, Maza I, Zviran A et al (2013) Derivation of novel human ground state naive pluripotent stem cells. Nature 504:282-286

Jaenisch R, Dubois N, Rasko JE, Deng H, Alvarado AS, Fuchs E, Novakovic GV, Baldwin K (2018) Challenging stem cells. Cell 173:1063-1065

James D, Levine AJ, Besser D, Hemmati-Brivanlou A (2005) TGFbeta/activin/nodal signaling is necessary for the maintenance of pluripotency in human embryonic stem cells. Development 132:1273-1282

Li H, Zhao C, Xu J, Xu Y, Cheng C, Liu Y, Wang T, Du Y, Xie L, Zhao $J$ et al (2018) Rapid generation of gene-targeted EPS-derived mouse models through tetraploid complementation. Protein Cell. https://doi.org/10.1007/s13238-018-0556-1

Martin GR (1981) Isolation of a pluripotent cell line from early mouse embryos cultured in medium conditioned by teratocarcinoma stem cells. Proc Natl Acad Sci USA 78:7634-7638

Nagy A, Rossant J, Nagy R, Abramow-Newerly W, Roder JC (1993) Derivation of completely cell culture-derived mice from early- 
passage embryonic stem cells. Proc Natl Acad Sci USA 90:8424-8428

Nichols J, Smith A (2009) Naive and primed pluripotent states. Cell Stem Cell 4:487-492

Takashima Y, Guo G, Loos R, Nichols J, Ficz G, Krueger F, Oxley D, Santos F, Clarke J, Mansfield W et al (2014) Resetting transcription factor control circuitry toward ground-state pluripotency in human. Cell 158:1254-1269

Tesar PJ, Chenoweth JG, Brook FA, Davies TJ, Evans EP, Mack DL, Gardner RL, McKay RD (2007) New cell lines from mouse epiblast share defining features with human embryonic stem cells. Nature 448:196-199

Theunissen TW, Powell BE, Wang H, Mitalipova M, Faddah DA, Reddy J, Fan ZP, Maetzel D, Ganz K, Shi L et al (2014) systematic identification of culture conditions for induction and maintenance of naive human pluripotency. Cell Stem Cell 15:524-526

Thomson JA, Itskovitz-Eldor J, Shapiro SS, Waknitz MA, Swiergiel JJ, Marshall VS, Jones JM (1998) Embryonic stem cell lines derived from human blastocysts. Science 282:1145-1147

Valamehr B, Robinson M, Abujarour R, Rezner B, Vranceanu F, Le T, Medcalf A, Lee TT, Fitch M, Robbins D et al (2014) Platform for induction and maintenance of transgene-free hiPSCs resembling ground state pluripotent stem cells. Stem Cell Rep 2:366-381

Wang $H$, Yang H, Shivalila CS, Dawlaty MM, Cheng AW, Zhang F, Jaenisch R (2013) One-step generation of mice carrying mutations in multiple genes by CRISPR/Cas-mediated genome engineering. Cell 153:910-918

Ware CB, Nelson AM, Mecham B, Hesson J, Zhou W, Jonlin EC, Jimenez-Caliani AJ, Deng X, Cavanaugh C, Cook S et al (2014) Derivation of naive human embryonic stem cells. Proc Natl Acad Sci USA 111:4484-4489

Yang H, Wang H, Shivalila CS, Cheng AW, Shi L, Jaenisch R (2013) One-step generation of mice carrying reporter and conditional alleles by CRISPR/Cas-mediated genome engineering. Cell 154:1370-1379

Yang J, Ryan DJ, Wang W, Tsang JC, Lan G, Masaki H, Gao X, Antunes L, Yu Y, Zhu Z et al (2017a) Establishment of mouse expanded potential stem cells. Nature 550:393-397

Yang Y, Liu B, Xu J, Wang J, Wu J, Shi C, Xu Y, Dong J, Wang C, Lai W et al (2017b) Derivation of pluripotent stem cells with in vivo embryonic and extraembryonic potency. Cell 169(243-257):e225 